\title{
Bioaccumulation of Iron in Plants and Their Possibilities as a Tool for Exploration of Hematite Ores
}

\author{
Ishor Parajuli, Mukesh Kumar Chettri \\ Department of Botany, Amrit Campus, Tribhuvan University, Kathmandu, Nepal \\ *Email.parajuliishwor17@gmail.com
}

(Received: 22 April, 2020, Received in revised form: 28 July, 2020, Accepted: 21 August, 2020, Available online)

\section{Highlights}

- Vegetation analysis along the hematite ores deposits was conducted at Dhaubadi, Nawalparasi (Ba.Su purba) area of Nepal and bioaccumulation of iron in plants in different sites was investigated.

- Because of high iron accumulation plants like Hypericum japonicum, Cyanotis vaga, Osbekia stellata, Gonostegia hirta, Trumphetta rhomboidea, Isodon coesta, and Begonia picta showed bronzing effect in the leaves and this coloration effect due to iron toxicity in plants should can be considered as indicator of hematite ore deposit.

- Based on high bioaccumulation factor, plant like Elsholtzia balnda and Anaphalis busua have been considered as good indicator of iron deposits and hence these plant species should be included as a tool during the exploration of new iron ore deposits.

\begin{abstract}
Relation of plant diversity with iron ore deposit area in Dhaubadi, Hupsekot rural municipality-5, Nawalparasi district, has been investigated in this study to explore good indicator and accumulator among plants. To identify this, plant diversity, iron accumulation in soil and plants growing on them at different plots were measured. Spermacoceae alata, Anaphalis busua, Isodon coesta and Salvia sclarea were common herbs in all plots and out of them Spermacoceae alata had the highest importance value index (IVI) value among herbs. Among the shrubs Ageratina adenophora, Maesa chisia, Osbekia stellate and Elsholtzia blanda were common in all the plots and of them Ageratina adenophora showed the highest IVI. Plant like Elsholtzia balnda and Anaphilis busua were identified as good indicator of iron deposits because of high amount of iron in their body, especially roots. Among all the sites, Begonia picta at the core area (Site A) had the highest iron accumulation, and most plants found there like Cyanotis vaga, Hypericum japonicum, Begonia picta, Gonostegia hirta, Trumphetta rhomboidea, Osbekia stellata and Isodon coesta had bronze coloration in leaves. The bronze coloration in leaves among plants has been identified as a good indicator to ascertain iron ore deposits.
\end{abstract}

Keywords: Plant diversity, Iron accumulation, Translocation factor, Bioaccumulation factor, Bronzing

\section{Introduction}

Plant species composition in mineralized area differs relative to neighboring non-mineralized areas and causes a dramatic differentiation in the physiognomy of the vegetation (Chettri et al., 1997, Banasova et al., 2006). The association of plant species with metalliferous soils has long been recognized (Antonovics et al., 1971) and the resulting concept of geo-botanical indicator has proved a very effective tool in mineral exploration (Baker \& Brooks, 1989). The metals Fe, Ti, Mn, Zn, Ga, Ag and Hg exhibit a close relationship between parent material and soil concentrations (Baker \& Brooks, 1989). Rumex acetosella and Minuartia

${ }^{*}$ Corresponding author 
verna (synonym Minuartia hirsute) were reported as indicators for copper ore deposits in Northern Greece (Ouzounidou, 1993; Chettri et al., 1997). Among plant parts, heavy metals were reported to be accumulated more in the roots than in shoots (Chettri et al., 1997). According to Raskin et al. (1997) very high elemental content in their ash as characteristic feature for metal indicator. In other words, a criterion for new indicators is that they should have a higher concentration of the element in their body than the surrounding vegetation.

Iron is an essential micronutrient for almost all living organisms as it plays critical role in metabolic processes such as DNA synthesis, respiration and photosynthesis. Further, many metabolic pathways are activated by iron, and it is a prosthetic group constituent of many enzymes such as cytochromes of the electron transport chain. In plants, iron is involved in the synthesis of chlorophyll hence, essential for the maintenance of chloroplast structure and function (Rout \& Sahoo, 2015). Iron is the third most limiting nutrient for plant growth and metabolism, primarily due to the low solubility of the oxidized ferric form in aerobic environments (Sharma et al., 2013). In aerobic soils, iron is predominantly found in the $\mathrm{Fe}^{+3}$ form.

Metal uptakes in higher plants are mostly from the root surface. After uptake of metal, the transport of metals may be either through the apoplast or symplast pathway, depending on metal species and their concentrations. Inside the plant, the apoplast has the free diffusional space outside the plasma membrane which helps in the transport of solutes and water across a tissue while the symplastic pathways helps in the diffusion of water and solutes (with low molecular weight) from cell to cell in the cytoplasm through the plasma membrane (Raskin et al., 1997). After root uptake, mobilized metal which is bound to the cell wall by apoplast pathway is mostly captured by the root cells (Ghosh \& Singh, 2005) and are transported to the shoot in very less amount. This is a common feature among many accumulator plants in mining areas (Chettri et al., 1997). In context to Nepal, geo-botanical work for the exploration of mining areas has not been known so far. It is not known if the plants growing in hematite ore are excluders or accumulators, and also it is not clear if they have similar uptake and accumulation in root and shoot. Hence to examine these facts, this geo-botanical study was carried out in Hematite ore area of Nawalparasi district, Central Nepal.

\section{Materials and Methods}

\section{Study area:}

Sampling site for this study was located at Dhaubadi, Hupsekot rural municipality-5, north-west side of Nawalparasi (Ba.Su purba) district, Nepal. This site was selected on the basis of the annual report of Department of Mining and Geology, where Pokhrel and Baskota (2013) reported that around $10 \mathrm{~km}$ Hematite deposited area is situated at Hupsekot rural municipality region. In these report two sites of hematite deposit have been identified and named as Block A and Block B. The present study was carried out in Block A and this site extended from $1500 \mathrm{~m}-1600 \mathrm{~m}$ above sea level (Fig: 1).The site is made up of mostly sedimentary and metamorphic rocks such as shale, sandstone, lime stone, dolomite, slate, schist and quartzite.

\section{Sampling procedure:}

Hematite deposit area of Block A was divided into four different sites A, B, C and D. The core area marked by Department of mining and geology on rocks was considered as site A. The areas about $100 \mathrm{~m}$ to $200 \mathrm{~m}, 300 \mathrm{~m}$ to $400 \mathrm{~m}$ and $800 \mathrm{~m}$ to $1000 \mathrm{~m}$ away from core area on east side was considered as site B,C and D. Control site was located on another fault of Mahabharat range(not shown in the map). At each site 5 quadrates of $10 \mathrm{~m} \times 10 \mathrm{~m}$ (for trees, Fig. 2) was

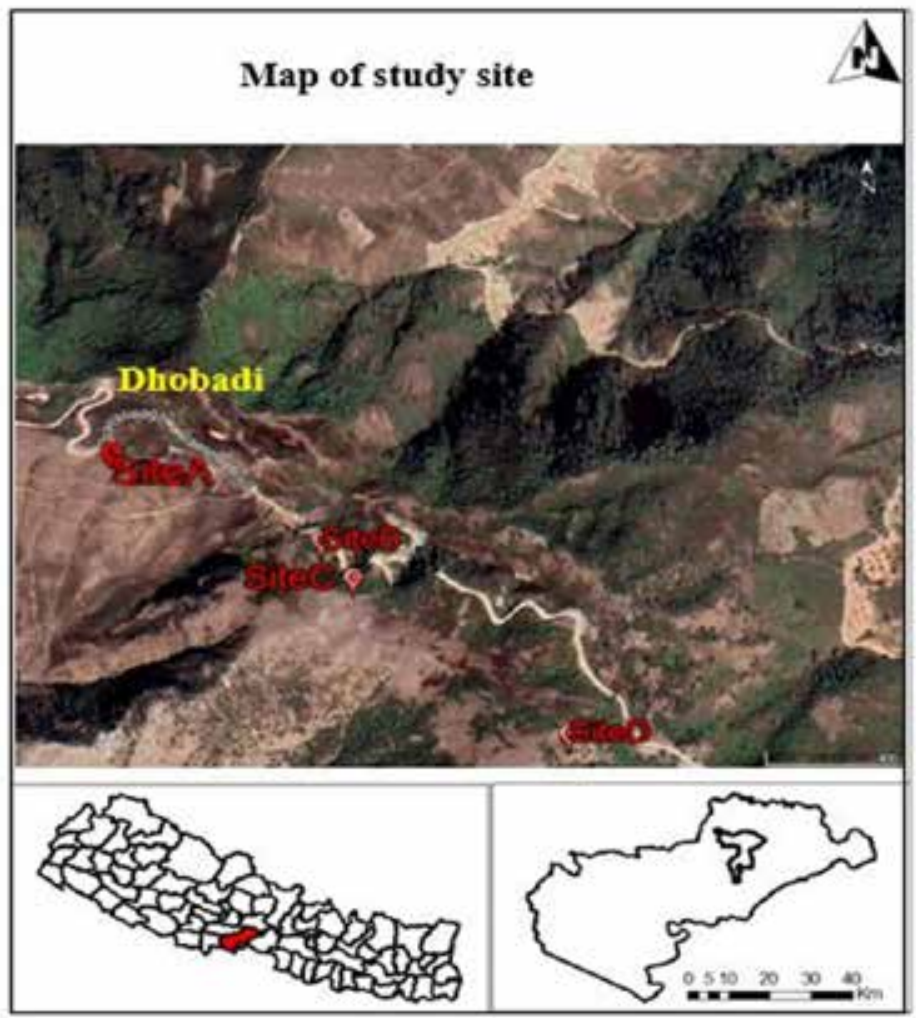

Fig 1. Map of Nepal-Nawalparasi (Ba.Su purba) Dhaubadi-Site with GIS coordination 
laid randomly and within that 3 quadrates of $5 \mathrm{~m} \times 5 \mathrm{~m}$ for shrubs and 3 quadrates of $1 \mathrm{~m} \times 1 \mathrm{~m}$ for herbs was laid, their coordinates were recorded and plotted in Figure 1. Three Soil samples from the surface to $15 \mathrm{~cm}$ depth were collected from each $10 \mathrm{mx} 10 \mathrm{~m}$ quadrate. All the quadrates were laid on eastern aspect of the mining sites because other aspects were with steep slopes.

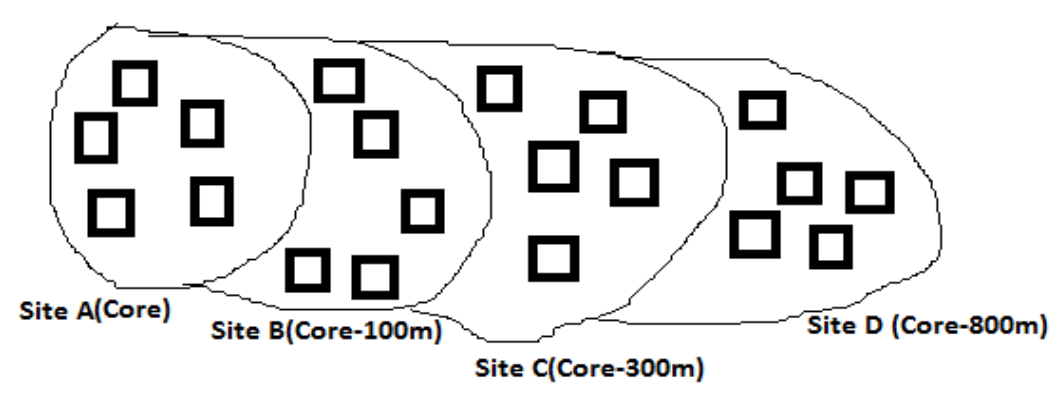

Fig 2. Diagrammatic representation of sampling sites in Block A.

\section{Vegetation analysis}

Plants were collected and herbaria were prepared for their identification. Frequency, relative frequency, density, relative density, coverage, relative coverage and finally Importance value index (IVI) was calculated for each plant species at sampling site using the formula given by Zobel et al. (1987).

\section{Metal analysis}

Plants samples were collected from each quadrats of each site and were cleaned carefully. All the foreign particles attached on the surface of plant materials were removed and washed thoroughly with running tap water to avoid soil contamination. The plant samples of each species collected separately from the each sites were dried at room temperature $23^{\circ}$ to $28^{\circ} \mathrm{C}$ for 2 days and then oven dried at $60^{\circ} \mathrm{C}$ for 48 hours. The dried materials of each species collected from the same sites were pulverized to get the representative sample. Metal analysis was performed according to wet digestion method 3050 of USEPA (1986) using atomic absorption Spectrophotometer.

\section{Translocation factor and bioaccumulation factor}

Translocation factor and bioaccumulation factor was calculated by using the formula given by Wilson et al. (2007).

$$
\text { Bioaccumulationfactor }(B A F)=\frac{\text { Conc. plant tissue }}{\text { Conc. soil }}
$$

On the basis of BAF, plant were further categorized as hyperaccumulator (BAF value $>1$ ), and accumulator or excluder (BAF value $<1)$.

Similarly, translocation factor was calculated according to the following equation given by Zacchini et al. (2009).

$$
\text { Translocationfactor }=\frac{\text { Concentration of Fe in shoot }}{\text { Concentratrations of Fe in root }}
$$

\section{Results}

\section{Vegetation analysis, Dhaubadi, Nawalparasi (Ba.su purba)}

The Hematite deposit Block A of Dhaubadi falls in the subtropical zone. Quercus lanata is the dominant tree species associated with Eurya acuminata and Lyonia ovalifolia. Plants that were recorded in different sites are given in Table 1 along with the iron content in shoot and root. Importance value index (IVI) of all plant species that were recorded in all sites (A, B, C and D) of Block A hematite deposit were calculated, The IVI value of herbs and shrubs that were commonly present in all sites are shown in Figure 4 and 5. A highest and lowest IVI value of each growth form at each site is summarized below. 
Site A: Altogether 14 herbs, 7 shrubs and 1 sapling of a tree were recorded at Site A However, mature tree was absent, while only one sapling of tree species Eurya acuminata recorded. Among the herbs highest importance value index (116.90) was recorded for Spermacoce alata and lowest was of Crysocephalum crepidiodes (3.64).Similarly, among the shrubs Ageratina adenophora had highest value (133.72) of IVI and Maesa chisia had the lowest (6.30).

Site B: Altogether 19 plant species were recorded; 8 herbs, 7 shrubs, 3 tree saplings and 1 tree species at site B. One tree of Rhododendron campanulatum and saplings of Eurya acuminata, Lyonia ovalifolia and Quercus lanata were recorded. Among the herbs Spermacoce alata (118.85) recorded the highest IVI value and Strobilanthes glutinosa (4.72) had the lowest IVI value. Among the shrubs Ageratina adenophora had highest IVI value (117.05) and Inula cappa had the lowest value (5.21). Among 3 saplings Eurya acuminata had highest IVI value (193.58) and Lyonia ovalifolia had the least IVI (35.43).

Site C: Altogether 19 plant species - 6 herbs, 8 shrubs, 3 tree saplings and 2 trees were recorded. Among the herbs highest IVI value (77.67) was recorded for Spermacoce alata and lowest was recorded in Salvia sclarea (6.23). Similarly, among the shrubsAgeratina adenophora (109.11) had highest IVI value and Inula cappa (10.13) had the lowest IVI. Sapling of Quercus lanata received highest IVI (177.44) and lowest was recorded for Lyonia ovalifolia (51.35). Among trees high IVI was obtained for Quercus lanata (185.45) and low IVI was recorded for Eurya acuminata (114.55).

Site D: Altogether 9 herbs, 6 shrubs and 1 tree saplings and 1 tree species were recorded in site D. Among the herbs highest IVI value (119.71) was recorded for Spermacoce alata and lowest for Gnaphilium affine (5.24). Similarly among the shrubs Ageratina adenophora (101.22) had highest IVI value and Maesa chisia had lowest IVI (13.27) in Site D.

Control: Altogether 7 herbs and 5 shrubs were recorded in control site. Among the herbs highest IVI value was recorded for Spermacoce alata (77.24) and lowest IVI was found for Isodon coesta (25.25). Similarly among the shrubs Maesa chisia recorded the highest value (109.88) of IVI and Inula cappa had the lowest IVI (20.39).

IVI of common herb and shrub: To understand if IVI values differ with sites, altogether 8 plant species ( 4 herbs and 4 shrubs) were considered that were found to be present in all Sites A, B, C and D. The IVI value of common herb species Spermacoceae alata was found to be highest at all sampling sites. IVI value of Anaphalis busua was comparatively low in Site A, B and D than in Site C and control. IVI of Isodon coesta was lowest in Site A than in Site B, C, D and control. Salvia sclarea mostly recorded lowest IVI in all sites except in site A.

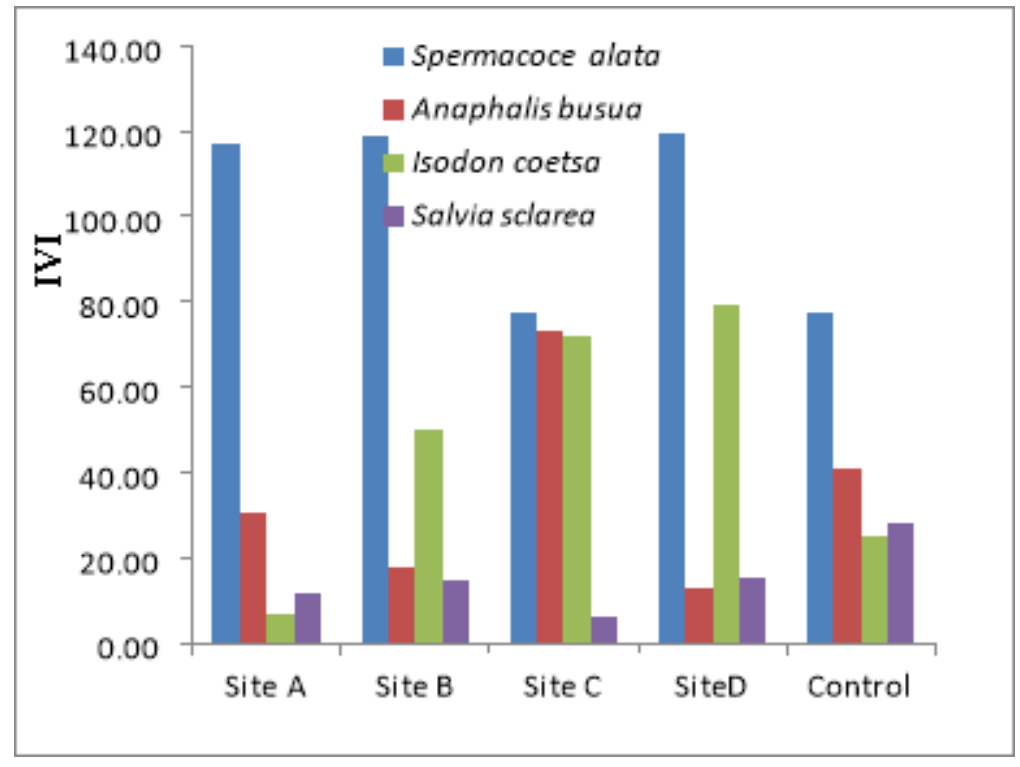

Fig 3. IVI of common herb species at different sampling sites.

Among the shrubs Ageratina adenophora showed the highest IVI value in all sites. Maesa chisia showed the highest IVI in control site but was comparatively low in all Sites A, B, C and D. Decreasing trend of IVI was observed in Osbekia stellata and Ageratina adenophora with distance away from the core areas and in control Elsholtzia blanda had more or less similar IVI value in all sites. 


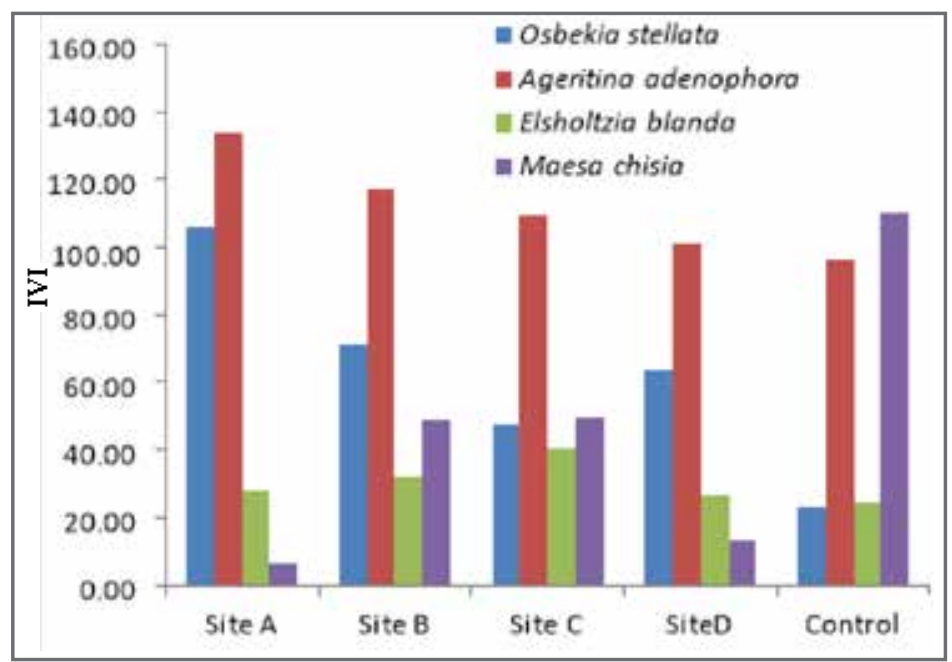

Fig 4. IVI of common shrub species at different sampling sites.

\section{Iron concentration in soil}

The iron concentration in soil is highest at Site A $(32,200 \mathrm{mg} / \mathrm{kg})$ and decreasing along the order at other sampling sites (B, $\mathrm{C}, \mathrm{D}$ and control) with increasing distance from Site

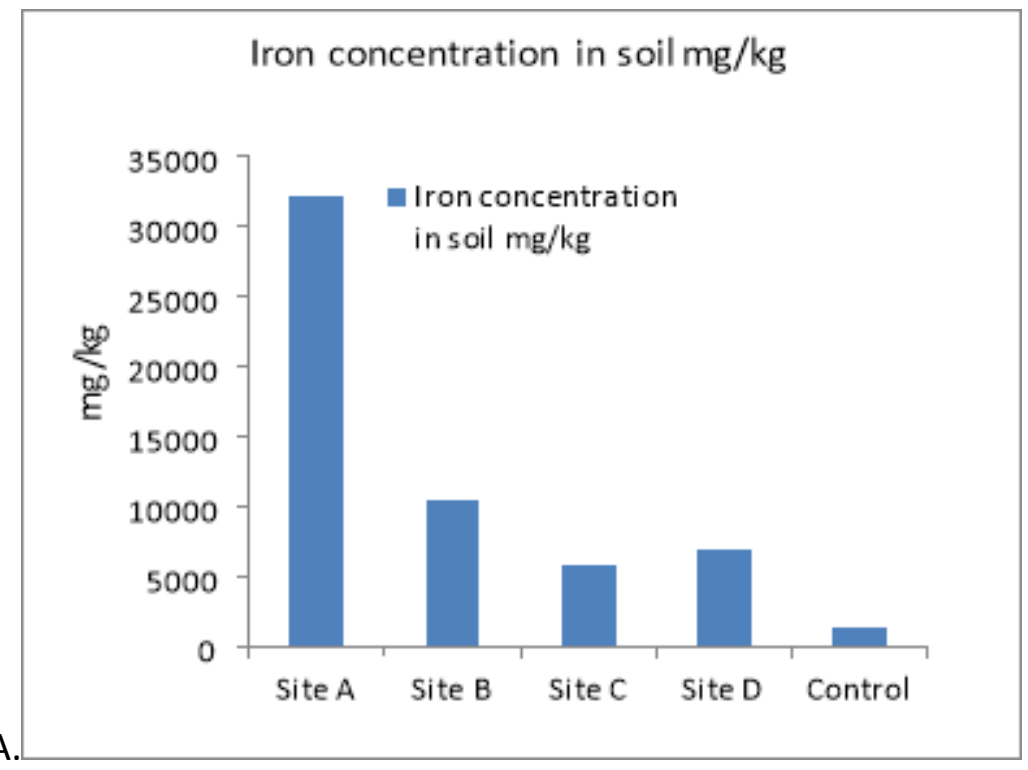

Fig 5. Iron concentrations in soil ( $n=15$ for each site) at different sampling sites.

\section{Iron concentration in plants}

The iron concentration in root and shoot parts of plants was measured (Table 1).Concentration of iron in roots was measured in plants that were common in all Sites. Among all plants at Site A shoot of Begonia picta reported highest iron concentration $(11300 \mathrm{mg} / \mathrm{kg})$ and least was in Hypericum uralum $(500 \mathrm{mg} / \mathrm{kg})$. Among the plants present at Site B, C and D root of Anaphilis busua had highest iron concentration $(7700 \mathrm{mg} / \mathrm{kg})$.

Table 1: Iron concentrations $(\mathrm{mg} / \mathrm{kg})$ in shoot and roots $*$ of plants collected from different sites of Iron deposits.

\begin{tabular}{|l|l|l|l|l|l|l|l|l|l|l|l|}
\hline Sampling sites & \multicolumn{2}{l|}{ Site A } & \multicolumn{2}{l|}{ Site B } & \multicolumn{2}{l|}{ Site C } & \multicolumn{2}{l|}{ Site D } & \multicolumn{2}{l|}{ Control } \\
\hline Name of species & shoot & root & shoot & root & shoot & root & shoot & root & shoot & root \\
\hline HERBS & & & & & & & & & & \\
\hline Spermacoce alata & 900 & 3700 & 800 & 1600 & 500 & 700 & 400 & 700 & 711 & 516 \\
\hline Anaphalis busua & 1600 & 8600 & 400 & 3700 & 600 & 7700 & 600 & 4500 & 5765 & 3957 \\
\hline
\end{tabular}




\begin{tabular}{|c|c|c|c|c|c|c|c|c|c|c|}
\hline Isodon coesta & 2000 & 2300 & 200 & 700 & 200 & 4000 & 400 & 2800 & 919 & 1210 \\
\hline Hypericum japonicum & 5500 & & & & & & & & & \\
\hline Begonia picta & 11300 & & & & & & & & & \\
\hline Phyllanthus urinaria & 2500 & & & & & & & & & \\
\hline Goldfussia nutans(Nees) & 4200 & & 1200 & & 1200 & & & & & \\
\hline Cyanotis vaga & 4600 & & & & & & & & & \\
\hline Gnaphilium affine & 3300 & & 1100 & & & & 600 & & & \\
\hline Gonostegia hirta & 1700 & & & & & & & & & \\
\hline Salvia sclarea & 800 & 3500 & 500 & 2000 & 200 & 5000 & 300 & 3200 & 398 & 1956 \\
\hline Crysocephalum cerepoides & 3500 & & & & & & 1200 & & & \\
\hline Bidens pilosa & 2300 & & & & & & 1700 & & & \\
\hline Solanum surattense & 2300 & & & & & & & & & \\
\hline Hedyotis scandens & & & 300 & & & & & & & \\
\hline Strobilanthes glutinosa & & & 200 & & 700 & & 900 & & & \\
\hline Flemingia macrophylla & & & & & & & 300 & & & \\
\hline \multicolumn{11}{|l|}{ SHURBS } \\
\hline Osbekia stellata & 1200 & 2300 & 600 & 2100 & 600 & 1500 & 300 & 300 & 416.67 & 595.69 \\
\hline Ageratina adenophora & 700 & 2200 & 200 & 900 & 400 & 1800 & 300 & 600 & 409.99 & 881.73 \\
\hline Elsholtzia blanda & 700 & 8500 & 400 & 1000 & 900 & 2000 & 300 & 1900 & 507.09 & 926.32 \\
\hline Rubus ellipticus & 2100 & & 600 & & & & & & & \\
\hline Trumphetta rhomboidea & 2800 & & & & & & & & & \\
\hline Hypericum uralum & 500 & & & & & & & & & \\
\hline Maeca chisia & 1200 & 3200 & 200 & 1000 & 300 & 900 & 200 & 400 & 416.67 & 562.34 \\
\hline Inula kappa & & & 400 & & 1700 & & 600 & & & \\
\hline Pogostemon bangalensis & & & 200 & & 1500 & & 900 & & & \\
\hline Colqhounia coccineae & & & & & 200 & & & & & \\
\hline Phyllanthus rhamnoides & & & & & 300 & & & & & \\
\hline \multicolumn{11}{|l|}{ SAPLINGS } \\
\hline Eurya acuminita & 1400 & & 300 & & 200 & & & & & \\
\hline Quercus Lanata & & & 200 & & 200 & & 400 & & & \\
\hline Lyonia ovalifolia & & & 200 & & 700 & & & & & \\
\hline \multicolumn{11}{|l|}{ TREES (Bark) } \\
\hline Rhododendron campanulatum & & & 400 & & & & & & & \\
\hline Eurya acuminita & & & & & 200 & & & & & \\
\hline Quercus lanata & & & & & 200 & & 400 & & & \\
\hline
\end{tabular}

(*Roots-Fe concentrations only measured in plants that were common in all sites)

The plants which were recorded exclusively in Site A only were Hypericum japonicum, Begonia picta, Phyllanthus urinaria, Cyanotis vaga, Gonestigia hirta, Solanum surattense, Trumphetta rhomboidea and Hypericum uralum. The bronzing coloration in leaves was observed in most of the plants like Hypericum japonicum, Cyanotis vaga, Osbekia stellata, Gonestigia hirta, Trumphetta rhonboidea, Isodon coesta, and Begonia picta that were growing in Site A. This bronzing coloration in leaf was observed only in Site A, but were absent in Site B, C and D. The bronzing coloration in plants seems to be an indicator that shows high concentrations of iron.

Herbs: Among the herbs the iron concentrations in shoots were higher in Site A than in Site B, C, D and control. The iron concentration in roots in all sites were mostly higher than in shoots (Fig: 6) except in control, where concentrations in shoots of Spermacoce alata and Anaphalis busua were higher in shoot than in roots. In all site, root of A.busua showed higher Iron concentration. Shoots of Isodon coesta in Site A, Spermacoce alata in site B and Anaphalis busua in site C, D and control showed highest iron accumulation. 


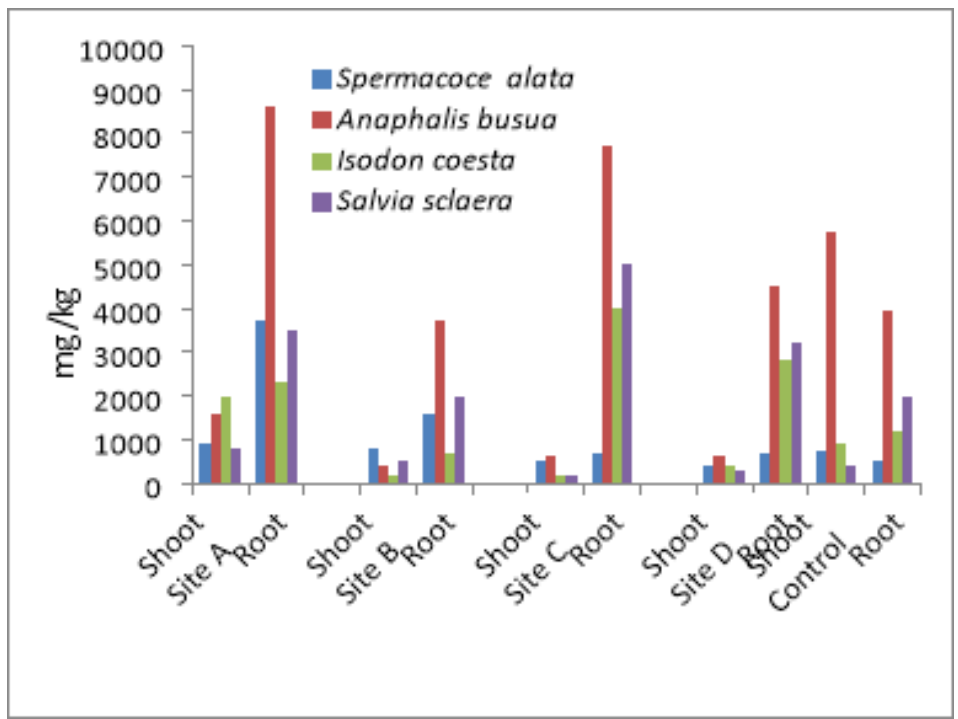

Fig 6. Iron concentrations $(\mathrm{mg} / \mathrm{kg})$ in shoot and root of common herb species at different sampling sites.

Shrubs: Roots of all shrubs recorded higher concentrations of iron than in their shoots. Among the shrubs root of Elsholtzia blanda showed highest iron accumulation in Site A, C, D and control, and the root of Osbekia stellata had high concentrations in site B (Fig 7). In all shrubs concentrations of iron in shoot is higher in Site A than in Site B, C, D and control.

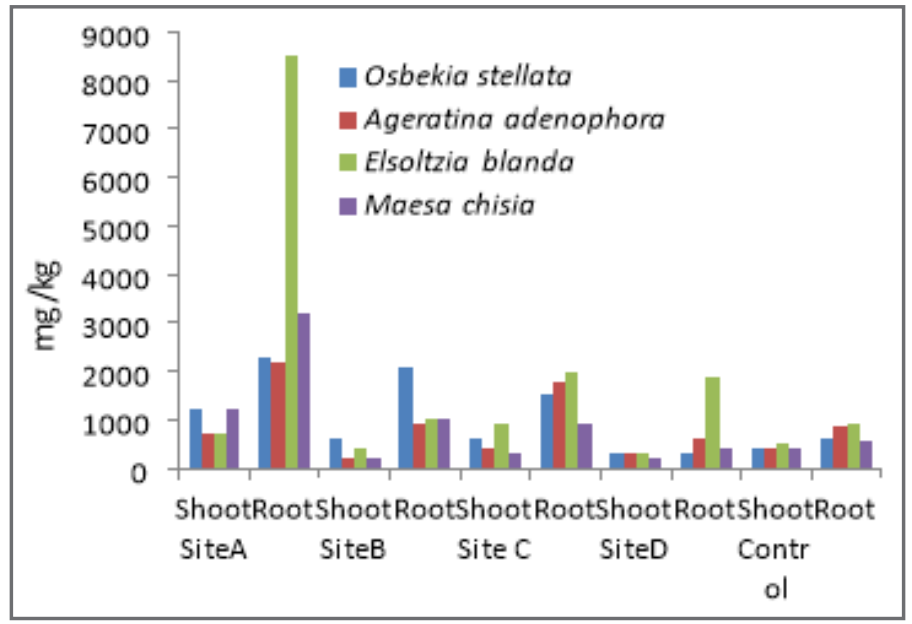

Fig 7. Iron concentrations $(\mathrm{mg} / \mathrm{kg})$ in shoot and root of common shrub species at different sampling sites.

\section{Translocation factor (TF)}

Herbs: Translocation factor is the value of shoot: root ratio. Translocation factor explains how much iron may go above at shoot region from roots in plants. Among the herbs, at Site A Isodon coesta had higher translocation factor (0.87) than other species. In Site B, C and D the herbs S. alata showed higher translocation factor than others. In Control Anaphalis busua showed higher translocation factor than others. The translocation factors of different species at different sites are summarized below.

Site A: Isodon coesta $>$ Spermacoce alata $>$ Salvia sclarea $>$ Anaphalis busua

Site B: Spermacocealta $>$ Isodon coesta $>$ Salvia sclarea $>$ Anaphalis busua

Site C: Spermacoce alta $>$ Anaphalis busua $>$ Isodon coesta $>$ Salvia sclarea

Site D: Spermacoce alata $>$ Isodon coesta $>$ Anaphalis busua $>$ Salvia sclarea

Control: Anapahilis busua $>$ Spermacoce alata $>$ Isodon coesta $>$ Salvia sclarea 


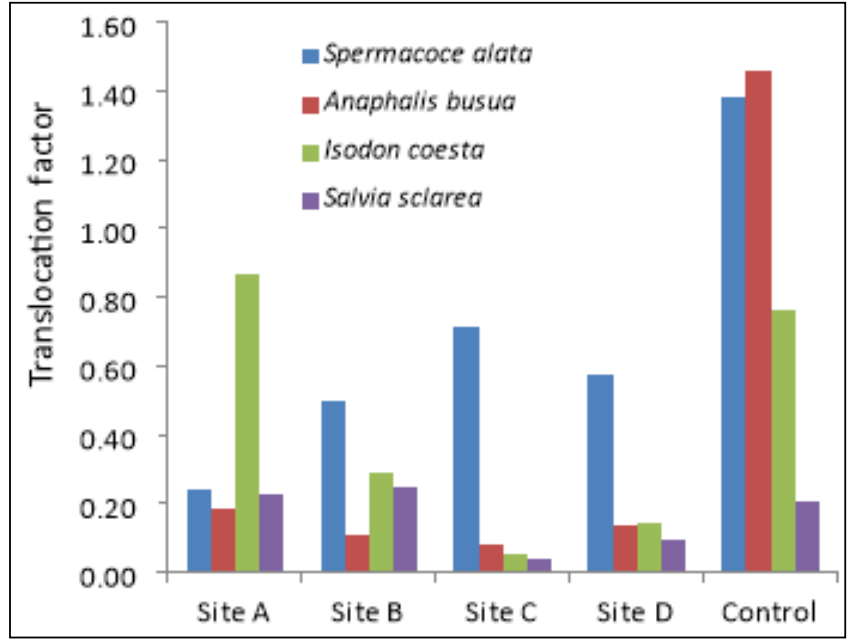

Fig: 9 Translocation factor of common herb species.

Shrubs: Among the shrubs, the translocation factor of Osbekia stellata in site D is 1, where the concentration of Iron in both shoot and root is $300 \mathrm{mg} / \mathrm{kg}$. The translocation factor of Osbekia stellata decreased when the concentration of iron in the plant body increased. This indicates the Osbekia stellata accumulates iron more in root and does not translocate to shoot when the iron concentration the soil is high. Same is the case with Elsholtzia blanda which shows less translocation factor in site A than in Site $\mathrm{B}, \mathrm{C}$ and control. The translocation factors of different species at different sites are summarized below.

Site A: Osbekia stellta $>$ Maesa chisia $>$ Ageratina adenophora $>$ Elsholtzia blanda

Site B: Elsholtzia blanda $>$ Osbekia stellata $>$ Ageritina adenophora $>$ Maesa chisia

Site C: Elsholtzia blanda> Osbekia stellata $>$ Maesa chisia $>$ Ageritina adenophora

Site D: Osbekia stellata $>$ Ageritina adenophora $=$ Maesa chisia $>$ Elsholtzia blanda

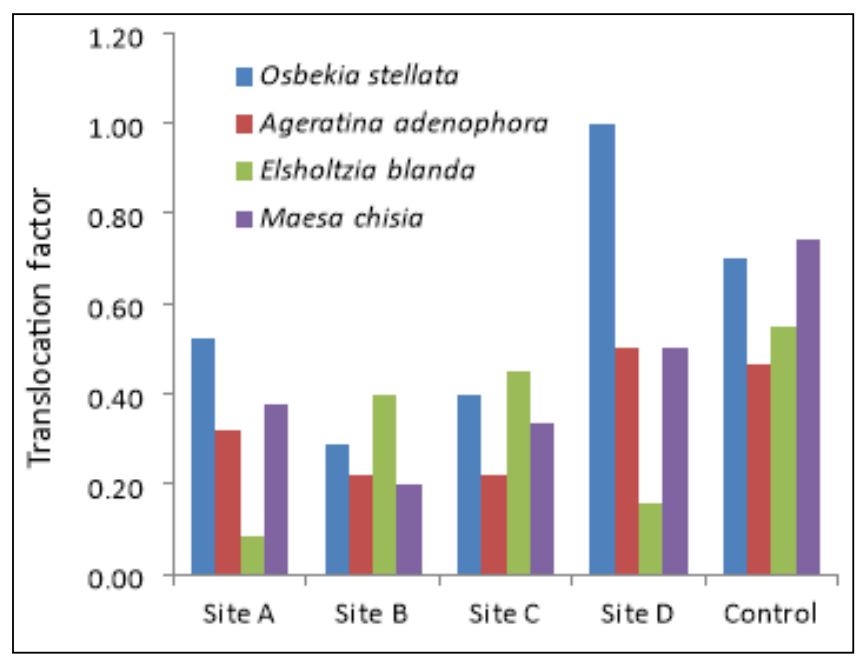

Fig 10: Translocation factor of common shrub species.

Control: Maesa chisia $>$ Osbekia stellata $>$ Elsholtzia blanda $>$ Ageritina adenophora

\section{Bioaccumulation factor (BAF)}

Herbs: Bioaccumulation factor (i.e. the ratio of iron concentration in plant tissue: Iron concentration in soil) among the herbs was low in Site A and B, but was high in Site C, D and Control. Highest bioaccumulation factor was observed in Anaphalis busua in all sites. Lowest bioaccumulation factor was seen in Isodon coesta at site B. The sequence of bioaccumulation factor at different sites is summarized below.

Site A: Anaphalis busua $>$ Spermacoce alata $=I$ sodon coesta $=$ Salvia sclarea

Site B: Anaphalis busua $>$ Salvia sclarea $=$ Spermacoce alata $>$ Isodon coesta

Site C: Anaphalis busua $>$ Salvia sclarea $>$ Isodon coesta $>$ Spermacoce alata

Site D: Anaphalis busua $>$ Salvia sclarea $>$ Isodon coesta $>$ Spermacoce alata

Control: Anaphilis busua $>$ Salvia sclarea $>$ Isodon coesta $>$ Spermacoce alata 


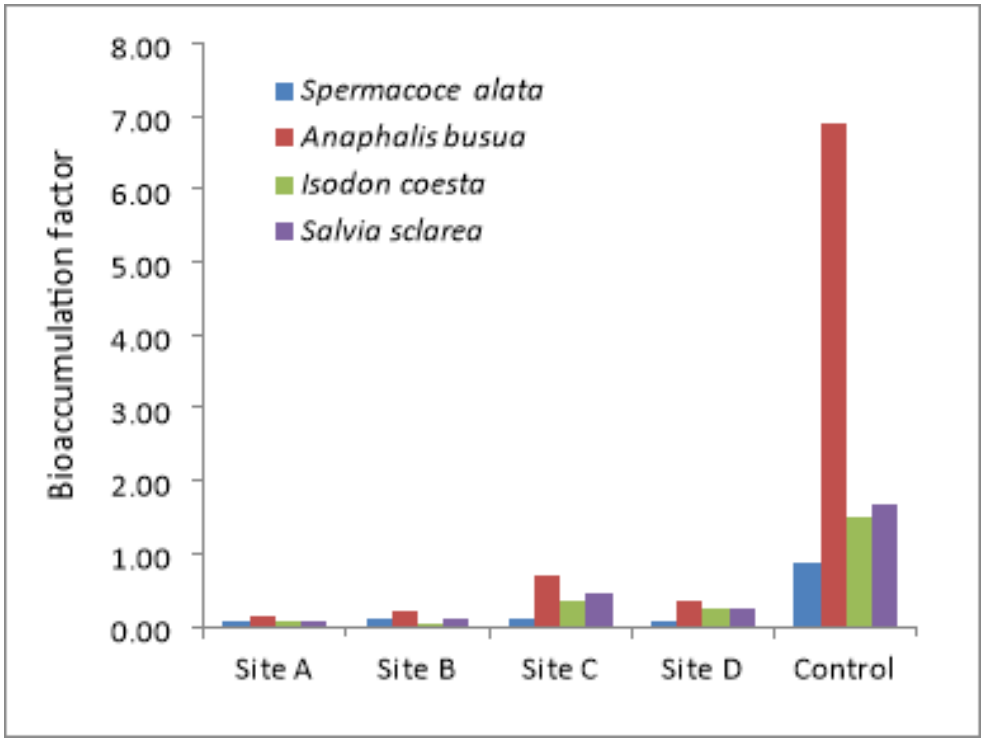

Fig: 11 Bioaccumulation factors of common herb species

Shrubs: Among all sites, highest bioaccumulation factor in shrubs was recorded in Control sites, where the concentration of iron was $1407 \mathrm{mg} / \mathrm{kg}$. Bioaccumulation factor among shrubs was low in Site B and Site D, but were higher in site A and C and control. Highest bioaccumulation factor was observed in Elsholtzia blanda in Site A, Site C and Site D. Lowest bioaccumulation factor was seen in Maesa chisia at Site A, C, D and Control. The sequence of bioaccumulation factor at different sites is summarized below.

Site A: Elsholtzia blanda $>$ Osbekia stellata $>$ Ageratina adenophora $>$ Maesa chisia

Site B: Osbekia Stellata $>$ Elsholtzia blanda $>$ Maesa chisia $>$ Ageratina adenophora

Site C: Elsholtzia blanda $>$ Ageratina adenophora $>$ Osbekia stelalta $>$ Maesa chisia

Site D: Elsholtzia blanda $>$ Ageratina adenophora $>$ Osbekia stellata=Maesa chisia

Control: Elsholtzia blanda $>$ Ageratina adenophora $>$ Osbekia stellata $>$ MAesa chisia

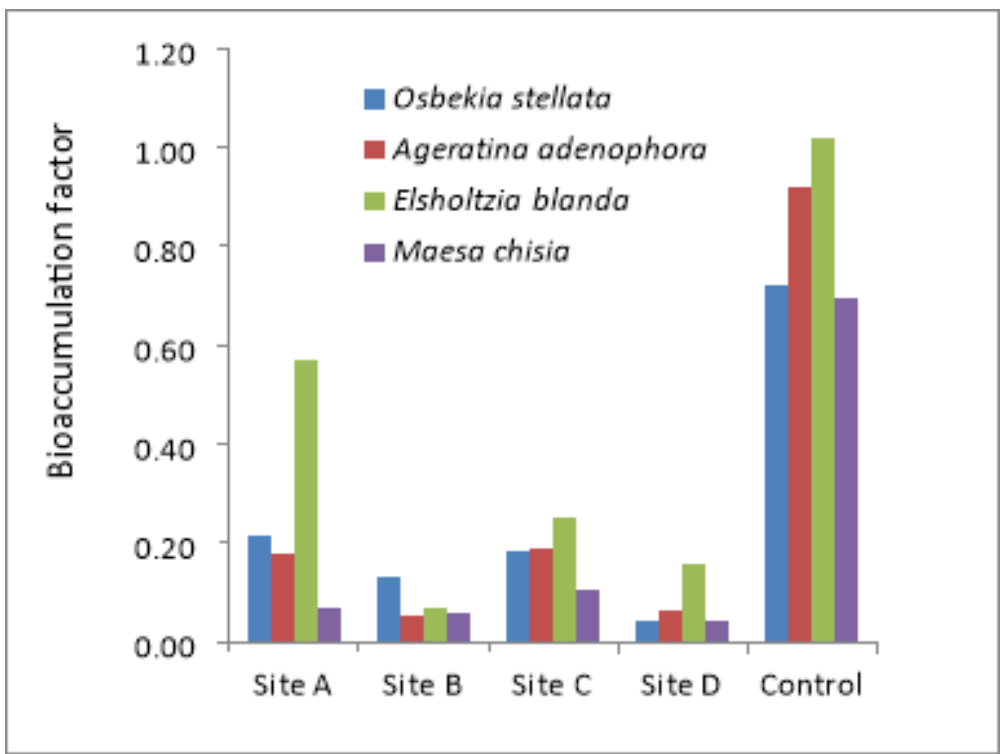

Fig: 12 Bioaccumulation factors of common shrub species 


\section{Discussion}

More number of plant species (22) was recorded at Site A than in site B, C and D ( 19, 19 and 17 plant species, respectively) might be due to open canopy with no trees in this site. Absence of trees in core area is possibly due to iron toxicity, as the concentration of iron is high in core soil sample in present study and similar finding was also recorded by Tyler (1984). High concentrations of one heavy metal in the soil also influences and reduces the availability of other essential trace elements like $\mathrm{Ca}, \mathrm{Mg}, \mathrm{Cu}, \mathrm{Zn}$ etc (Sharma and Chettri,2008) and this might lead to uncongenial environment for the establishment and survival of trees. The saplings of trees species like Eurya acuminata, Lyonia ovalifolia, Quercus lanata and Rhododenrone campanulatum could differently withstand iron concentration in soil. Eurya acuminata sapling were found up to $32200 \mathrm{mg} / \mathrm{kg}$ iron concentration in soil and Quercus lanata and Lyonia ovalifolia sapling were found up to $10,400 \mathrm{mg} / \mathrm{kg}$ iron concentration. These trees species could grow in such a high iron concentrations because of their avoidance mechanism, which is evident from the iron concentration in the bark, which is comparatively very low ranging from 200 to $400 \mathrm{mg} / \mathrm{kg}$. This clearly showed that these tree species must have accumulated iron in their roots and supplied very less amount to the shoots, the survival strategy and metal avoidance mechanism, very common among plants growing on metalliferous soil.

The IVI value of common herb species Spermacocea alata, a perennial herb of Rubiaceae family was found to be highest at all sampling sites. It is also a very common plant in forest floor and grazing land because it is good forage and their seeds are easily distributed through cattle. Besides this the multiplication of Spermacocea through vegetative propagation from every node is very common. The mature plants crawl over the soil surface and new shoots arise from the nodes very frequently. Similarly, Ageratina adenophora, an invasive shrub, showed the highest IVI value. This may be due to their invasive characters like large number of seed production, exudation of allele-chemicals, and vegetative propagation from the nodes of the stem. Light stimulates seed germination in Ageratina adenophora, which must be helped in invading barren or heavily disturbed areas (Wang et al., 1994).

\section{Iron accumulation}

Iron is one of most essential elements for the growth and development of plants. More accumulation in root was observed than in shoot in all plants indicating that the iron is more accumulated in root and as slowly translocated to shoot region. The translocation factor in Isodon coesta is quite high in site A where iron concentration in soil is high but it was not observed in site $\mathrm{B}, \mathrm{C}$ and $\mathrm{D}$ this might be due to low concentration of iron in soil, which might have helped in uptake of other essential ions and this probably might have reduced the translocation of iron to the shoot region in rice Tanaka and Navasero (1966).The bronzing coloration in leaves of Hypericum japonicum, Cyanotis vaga, Osbekia stellata, Gonestigia hirta, Trumphetta rhomboidea, Isodon coesta, and Begonia picta that were growing in Site A is possibly due to toxic effect of iron accumulation Becker \& Asch (2005).

The translocation factor of Spermacoce alata is quite high in site $\mathrm{C}$ and $\mathrm{D}$, where the iron concentration in soil is comparatively lower than in site A and B. This high translocation factor in Spermacoce alata is mainly due to low accumulation of iron in root region. Iron being essential elements, the translocation up to certain concentration might not have been obstructed by the root. Among the shrubs mostly Osbekia stellata showed high translocation factor in sites A.D and control. Plants with high Translocation factor are classified as high efficiency plant for metal translocation (Rezvani \& Zaefarian, 2011) and hence Osbekia stellata can be considered as efficient plant for metal translocation from this study,

Among shrubs highest bioaccumulation factor was observed in Elsholtzia blanda and among herbs it was observed in Anaphalis busa in all sites. High bioaccumulation of iron in the roots of these species in all sites have indicated them to be a good bioaccumulator. From this study it can be ascertained that the plant like E. blanda and A. busa should be include for monitoring iron content in soil in future.

Besides this Elsholtzia blanda is a metal tolerant species and have no effect on biomass as they are metal-excluder plant (Tang et al. 2001) hence it could accumulate large iron concentration in root region. A. busua is a perennial plant with good root system and could accumulate large amount iron in its root system. Because of the high bioaccumulation of Iron in Elsholtzia blanda and Anaphalis busua, these two plants can be considered as a good indicator for iron ore exploration. 


\section{Conclusions}

From this study it can be concluded that though iron is essential elements for plants but very high concentrations of iron in soil (around $30,000 \mathrm{mg} / \mathrm{kg}$ ) do not support trees, which may be due to depletion of other essential elements. The bronze coloration of shoots in plants like Cyanotis vaga, Hypericum japonicum, Begonia picta, Gonostegia hirta, Trumphetta rhomboidea, Osbekia stellata and Isodon coesta indicated large amount of iron accumulation in plants and this morphological coloration effects should be considered as indicator for exploration of iron ore deposits. Besides this the bioaccumulation factor in herb Anaphalis busua and shrub Elsholtzia blanda are high, hence these plants should also be included as tool of geo-botany for exploration of iron ore deposits.

\section{Acknowledgement}

The first author acknowledges thanks to the Botany Department, Amrit Campus, Tribhuvan University, to provide space and laboratory facilities during this research work.

\section{References}

Antonovics, J., Bradshaw, A. D. and Turner, R. G. 1971. Heavy Metal Tolerance in Plants. Advances in Ecological Research. 7(C): $1-85$.

Baker, A J. M. and Brooks, R. R. 1989. Terrestrial higher plants which hyperaccumulate metallic elements - a review of their distribution, ecology and phytochemistry. Biorecovery. 1(2): 81-126.

Banásová, V.1, Horak, O, Čiamporová, M, Nadubinská, M. and Lichtscheidl, I. 2006. The vegetation of metalliferous and nonmetalliferous grasslands in two former mine regions in Central Slovakia. Biologia, Bratislava, 61 (4): 433—439,

Becker, M., Asch, F. 2005. Iron toxicity in rice-condition and management concepts. Journal of Plant Nutrition and Soil Science. 168: 558-573.

Chettri, M. K., Sawidis, T. and Karataglis, S. 1997. Lichens as a tool for biogeochemical prospecting. Ecotoxicology and Environmental Safety. 38: 322-335.

Ghosh, M. and Singh, S.P . 2005.A review on phytoremediation of heavy metals and utilization of it's by products. Asian journal on energy and Environment. 6( 04):214-231.

Ouzounidou, G. 1993. Heavy metal effects on natural plant species of Northern Greece's metalliferous soil. Ph.D. Thesis. Aristotle University of Thessaloniki, Greece.

Pokhrel K.N. and Baskota N. 2013. Preliminary and follow-up explorations of hematite deposit in Dhaubadi-Pokhari area, Nawalparasi district. Annual report of department of Mines and Geology. No. 9\&10, 1-6

Raskin, I., Smith, R. D. and Salt, D. E. 1997. Phytoremediation of metals: Using plants to remove pollutants from the environment. Current Opinion in Biotechnology.8 (2):221-226.

Rezvani, M. and Zaefarian, F. 2011. Bioaccumulation and translocation factors of cadmium and lead in "Aeluropus littoralis." Australian Journal of Agricultural Engineering. 2(4): 114-119.

Rout, G. R. and Sahoo, S. 2015. Role of iron in plant growth and metabolism. Reviews in Agricultural Science. 3: 1-24

Sharma, B. and Chettri, M. K. 2008. Impact of heavy metals on accumulation of micronutrients and chlorophyll content of higher plant. Pollution Research 27 (2):355-363

Sharma, A., Shankhdhar, D. and Shankhdhar, S. C. 2013. Enhancing grain iron content of rice by the application of plant growth promoting rhizobacteria. Plant, Soil and Environment. 59(2): 89-94. 
Tanaka, A. and Navasero, S. A. 1966. Interaction between iron and manganese in the rice plant. Soil Science and Plant Nutrition. 12(5): 29-33.

Tang, S., Wilke, B. M. and Brooks, R. R. 2001. Heavy-metal uptake by metal-tolerant Elsholtzia haichowensis and Commelina communis from China. Communications in Soil Science and Plant Analysis. 32(5-6): 895-905.

Tyler, G. 1984. The impact of heavy metal pollution on forests: A case study of Gusum, Sweden. Ambio. 30(1): 18-24.

Wang HJ, He P. and Ma J.L. 1994. An investigation and research report on the dissemination of Ageratina adenophora on rangeland areas in Liangshan District of Sichuan Province.Grassland China 1:62-64

Wilson, B. and Pyatt, F. B. 2007. Heavy Metal Bioaccumulation by the Important Food Plant, Olea europaea L., in an Ancient Metalliferous Polluted Area of Cyprus . Bulletin of Environmental Contamination and Toxicology. 78(5):390-394

Zacchini, M., Pietrini, F., Scarascia Mugnozza, G., Iori, V., Pietrosanti, L. and Massacci, A. 2009. Metal tolerance, accumulation and translocation in poplar and willow clones treated with cadmium in hydroponics. Water, Air, and Soil Pollution. 197(14): $23-34$.

Zobel, D. B, Jha, P. K, Behm, M. J. and Yadav, U. K. R. 1987. A Practical Manual for Ecology. Ratna Book Distributors, Kathmandu. 